\title{
Quantitative land evaluation of the Chuka-South area, Kenya
}

\author{
A. Veldkamp (Department of Soil Science and Geology, Wageningen Agricultural \\ University, P.O. Box 37, 6700 AA Wageningen, Netherlands)
}

Received 12 October 1987; accepted 19 January 1988

\begin{abstract}
Evaluation of land in the Chuka-South area of central Kenya indicates that there is ample scope for yield increase. Calculated water-limited yield potentials are far above actual yields. Nutrient-limited yield potentials are roughly half the water-limited yields, i.e. natural soil fertility of the Chuka-South area is low. The effects on yield levels of alternative water conservation measures have been evaluated for the eastern half of the area. The evaluation indicates that a fair yield increase can be expected from prolonged mulching in the area between 700 and $1000 \mathrm{~m}$.
\end{abstract}

Key words: quantitative land evaluation, Kenya, yield potential, Chuka-South

Introduction. In 1985, the Training Project in Pedology of the Department of Soil Science and Geology, Wageningen Agricultural University, started surveying the Chuka-South area (central Kenya), with the main aim of producing a soil map and a map of land suitability. The results are presented of a first attempt to evaluate physical aspects of land suitability for arable cropping. The reader is supposed to be familiar with the theories on quantitative land evaluation (Driessen, 1986). For general information on the Chuka-South area, see 'Soils of the Chuka-South area' (de Meester \& Legger, 1987).

Material and methods. For the evaluation, a modified version of the agricultural production model developed by the Centre for World Food Studies (van Keulen \& Wolf, 1986) was used. Calculated and estimated results are presented on maps (1:400 000), drawn with UNIRAS on a main-frame computer (VAX 8600). All data used are allocated to the appropriate cells $\left(1 \mathrm{~km}^{2}\right)$ of a predetermined grid. Two different yield potentials are calculated. For calculation of water-limited yield the only environmental conditions considered were solar radiation, temperature, evaporative demand, precipitation and physical properties of soil related to infiltration and availability of moisture. For calculation of nutrient-limited yield, chemical and physical properties of soil related to base uptake (i.e. nutrient uptake without fertilizer application) and recovery (i.e. fertilizer requirement in relation to crop properties) were introduced as possible growth-limiting factors.

The water-limited yield potentials of selected crops were calculated for 20-year periods. Fertilizer requirements with the water-limited yields were also calculated for some crops. The nutrient-limited yield potential of one crop calculated accord- 


\section{A. VELDKAMP}

ing the QUEFTS model (Janssen et al., 1987) was compared with results of fertilizer trials. All calculated results were compared with estimates of actual yield. The effects of some measures for water conservation were evaluated, and finally, the results of the quantitative procedure of land evaluation were compared with those of a qualitative procedure.

Results. Water-limited yield potential was calculated for maize, sorghum, millet, tobacco, cotton, chickpea, mung bean, soya, cassava, sweet potatoes, potatoes and rice. In general, water-limited potential increased with altitude, mainly because the rainfall increased. In the high western part of the area, the water-limited yield potentials were high, since yield reductions due to lack of water were absent or small, whereas in the lower eastern part yield potential was generally low to very low through lack of water. Spatial differences in water-limited yield potentials were partly zonal and related to climatic differences with altitude, and partly local in response to variations in physical properties of the soils. Most crops had a production optimum between 1400 and $1800 \mathrm{~m}$. At higher altitudes, unfavourable temperatures or persistent waterlogging limited production. Maps of calculated requirements for $\mathrm{N}$ and $\mathrm{P}$ showed similar patterns to the maps of water-limited yield potentials. The fertilizer requirements were highest in the western part of the ChukaSouth area, where water-limited yield potential was highest and natural soil fertility was low. The uptake of $\mathrm{N}$ and $\mathrm{P}$ from the different soil types was far below the requirement for the water-limited yield potentials. The nutrient-limited yield potentials of the various crops were therefore considerably below the water-limited yield potentials. In comparison with control yields from FAO fertilizer trials (19701972), both maps indicate similar nutrient-limited yield potentials between 0 and $4000 \mathrm{~kg} / \mathrm{ha}$ (the water-limited yields range between 0 and $10000 \mathrm{~kg} / \mathrm{ha}$ ). Actual yields obtained in an open system, where probably no yield-limiting factor is permanently optimun, were the only expression of the real system's full complexity. The trends in 'real average' yields were compared with those of the calculated waterlimited and nutrient-limited yield potentials for some crops. All real yields were far below the calculated yield potentials. The low real yield potentials between 700 and $1000 \mathrm{~m}$ were probably mainly limited by soil fertility ( $\mathrm{N}$ and $\mathrm{P}$ ) and by high run-off: the fertile top soil was eroded.

As a side-line, the impact of possible measures, such as ploughing and mulching or fallow, on calculated yield potentials was evaluated for maize and millet. Ploughing, represented in the model by a $10 \%$ increase in infiltration resulted in no significant increase in yield for either crop. The model predicted that mulching or fallow, represented in the model by a $30 \%$ increase in infiltration, would considerably increase water-limited yield potential for maize and moderately increase yield for millet. The long-term effect of mulching and fallow was that infiltration rates will either increase or stabilize. Soil fertility $(\mathrm{N})$ and nutrient availability would probably increase too with fallow.

Conclusions. There seems to be ample scope for increasing crop production in the Chuka-South area. Groundnut and soya, which are rarely grown in the area at pres- 
ent, showed promising water-limited yield potentials. The calculated nutrient-limited yield potentials were roughly half the water-limited yield potentials, i.e. natural soil fertility of the Chuka-South area was low. The nutrient-limited yield potentials could be doubled in the western part of the area if fertilizers were applied in the proper manner. It is the author's general impression that, in the long term, a fair yield increase could be expected if mulching were to become a standard procedure in the (semi) permanent farming systems in the eastern half of the Chuka-South area (between 700 and $1000 \mathrm{~m}$ ).

The Chuka-South area was evaluated according to qualitative (de Meester \& Legger, 1987) and quantitative procedures. Both land approaches indicated the same general tendencies. The advantages of the quantitative procedure was that its dynamic approach allows easy evaluation of the effects of changes in physical environment. The quantitative procedure had certain disadvantages too. It needed 'accurate' quantitative data, which is lacking. Crops like coffee and tea cannot be evaluated by the present model.

\section{References}

Driessen, P. M., 1986. The Q.L.E. primer, a first introduction to quantified land evaluation procedures. Lecture notes Department of Soil Science and Geology, Agricultural University, Wageningen.

Janssen, B. H. et al., 1987. Quantitative evaluation of the fertility of tropical soils. Department of Soil Science and Plant Nutrition, Agricultural University, Wageningen.

Keulen, H. van \& Wolf, J. (Eds), 1986. Modelling of agricultural production: weather, soils and crops. Pudoc, Wageningen.

Meester, T. de \& Legger, D. (Eds), 1987. Soils of the Chuka-South area, Kenya. Department of Soil Science and Geology, Agricultural University, Wageningen/Kenya Soil Survey, National Agricultural Laboratories, Ministry of Agriculture, Nairobi.

This synopsis is based on an undergraduate thesis 'A quantified land evaluation of the Chuka-South area, Kenya' by A. Veldkamp, Department of Soil Science and Geology, Wageningen Agricultural University, Wageningen, 1987. 44 pp., 37 figs., 6 tables, 23 refs., 1 appendix. Available as paper copy (order R080P, $f 10$ including postage) at: NARD, clo Pudoc, P.O. Box 4, 6700 AA Wageningen (telex 45015 blhwg). 